\title{
Erratum to: A de novo whole gene deletion of XIAP detected by exome sequencing analysis in very early onset inflammatory bowel disease: a case report
}

Judith R. Kelsen ${ }^{1,10^{*+}}$, Noor Dawany ${ }^{2 \dagger}$, Alejandro Martinez ${ }^{1}$, Christopher M. Grochowski ${ }^{3}$, Kelly Maurer ${ }^{4}$, Eric Rappaport', David A. Piccoli', Robert N. Baldassano ${ }^{1}$, Petar Mamula', Kathleen E. Sullivan ${ }^{4}$ and Marcella Devoto ${ }^{6,7,8,9}$

Following publication of the original version [1] of the article in BMC Gastroenterology it was brought to our attention that the author's name has been incorrectly spelt, instead of 'Alejuandro' it should be spelt 'Alejandro'.

\section{Author details}

'Division of Gastroenterology, Hepatology, and Nutrition, The Children's Hospital of Philadelphia, Philadelphia, PA, USA. ${ }^{2}$ Department of Biomedical Health Informatics, The Children's Hospital of Philadelphia, Philadelphia, PA, USA. ${ }^{3}$ Department of Pathology and Laboratory Medicine, The Children's Hospital of Philadelphia, Philadelphia, PA, USA. ${ }^{4}$ Division of Immunology and Allergy, The Children's Hospital of Philadelphia, Philadelphia, PA, USA.

${ }^{5}$ Nucleic Acid/PCR Core, The Children's Hospital of Philadelphia, Philadelphia, PA, USA. ${ }^{6}$ Division of Human Genetics, The Children's Hospital of Philadelphia, Department of Pediatrics, Department of Biostatistics and Epidemiology, Perelman School of Medicine, University of Pennsylvania; Department of Molecular Medicine, University Sapienza, Rome, Italy. ${ }^{7} 7 \mathrm{NW}$, Division of Pediatric Gastroenterology, The Children's Hospital of Philadelphia, 3400 Civic Center Blvd, Philadelphia 19104 PA, USA ${ }^{8}$ Department of Pediatrics, University of Pennsylvania, Philadelphia, USA. ${ }^{9}$ Department of Molecular Medicine, University Sapienza, Rome, Italy. ${ }^{10}$ Department of Biostatistics and Epidemiology, Perelman School of Medicine, University of Pennsylvania, Philadelphia, USA.

Received: 11 December 2015 Accepted: 14 December 2015 Published online: 18 December 2015

\section{Reference}

1. Kelsen JR, Dawany N, Martinez A, Grochowski CM, Maurer K, Rappaport E, et al. A de novo whole gene deletion of XIAP detected by exome sequencing analysis in very early onset inflammatory bowel disease: a case report. BMC Gastroenterol. 2015;15:160.

\footnotetext{
* Correspondence: Kelsen@email.chop.edu

${ }^{\dagger}$ Equal contributors

'Division of Gastroenterology, Hepatology, and Nutrition, The Children's Hospital of Philadelphia, Philadelphia, PA, USA

${ }^{10}$ Department of Biostatistics and Epidemiology, Perelman School of Medicine, University of Pennsylvania, Philadelphia, USA

Full list of author information is available at the end of the article
}

\footnotetext{
Submit your next manuscript to BioMed Central and we will help you at every step:

- We accept pre-submission inquiries

- Our selector tool helps you to find the most relevant journal

- We provide round the clock customer support

- Convenient online submission

- Thorough peer review

- Inclusion in PubMed and all major indexing services

- Maximum visibility for your research
}

Submit your manuscript at www.biomedcentral.com/submit 